\title{
THE INTENTION TO USE E-GOVERNMENT SYSTEM (E-EXPORTING) IN SHIPPING AND EXPORTING COMPANY IN LIBYA
}

\author{
Dhwo Jubran \\ Ali Djamhuri \\ Zaki Baridwan \\ University of Brawijaya
}

\begin{abstract}
Recently, many countries, either developing or developed, concern about the e-government as a new project. They took it in their account by paying more attention about this project. This paper was conducted in a shipping and exporting company by distributing questionnaires over 110 finance and admission employees. It employs TAM's and UTAUT's model to determine the main factors influencing the intention to use E-government system. The factors being on account are perceived usefulness, perceived ease of use, trust, and awareness. Their correlations with the dependent variable (intention to use e-government) have been examined. The researcher added two moderating variables (Age \& Experience) to investigate their impact on the direct relationship between the independent and dependent variables. However, government considers that there is remarkable lack of acceptance on the new system which includes egovernment from the employees, even the whole citizens. This problem is faced by the Libyan government. Thus, this paper tried to find the causes behind the lack of acceptance of the employees upon the new system. The results obtained are reliable enough for the use of statistical tool which is PLS program that is derived from SEM. For instance, the obtained result demonstrates that the perceived usefulness has non-significant relationship but the perceived ease of use; trust and awareness have significant relationship toward intention to use E-government system.
\end{abstract}

Key words: TAM's model, UTAUT's model, trust, awareness, intention to use e-government. 


\section{INTRODUCTION}

E-government in general can be defined as the internet application enabling the government to serve the public accessing resource in general in order to interact easily with the government including in gaining government information(Huang, 2003). Egovernment can also be known as the use of information technology to increase efficiency and effectiveness in processing the government's documents as well as transactional exchange between government and particular organizations or among the governments themselves(Turban, 2004).

It is very clear that all developing countries suffer from the lack of acceptance of new information technology used as a system known as e-government Riyadh, Hosam Alden, Sukoharsonom, Eko Ganis \& Baridwan Z.(2015). This problem is undergone by most developing countries. Libyan government has set up some parts of e-government and it suffers from the lack acceptance of the citizens for some ambiguous reasons. Basically, after the revolution, Libya participated the United Nation Development Program (UNDP) to improve the skills of processing e-government. In addition, about $91 \%$ of Libyan citizens are literate, but on the other hand the investors are unstable even getting worse for the lack of budget funding. Based on that low level of acceptance, egovernment becomes the main reason for decreasing the investment budget (Aref, 2016; UNDP, 2013). This research is going to investigate and analyze some factors that cause its low level of acceptance as well as its impact on e-government.

E-government in this research will be demonstrated through an E-system that has been established in the company studied. This system is called E-exporting which can illustrate and give a broad understanding about E-government because it is a part of E-government. Furthermore, the employee's intention to use E-government will also be explored through the study of this company. This research is following TAM theory which has established two variables (perceived usefulness and perceived ease to use), then it has followed by trust and awareness variables, which have derived from a previous study that applied in Bahrain as a developing country, in order to have full understanding of the e-government usage. In addition to that the UTAUT (Unified Theory of Acceptance and Use of Technology) will be used to show the effecting of the moderating variables (Age and Experience) on the relationship between the independent variables and the dependent variable. For instance, this research will inform the employees who are part of citizens and the government itself about the location of the weakness of paying intention to use of e-government. Thus, the government sought to figure out the radical problem and try to establish the solution down in order to capture the majority of the chances such as collecting taxation, e-procurement, e-checking and so on. Trying to find the solution will expand the wide board of using the e-government services.

The inspiration to give electronic-based taxpayer driven organizations from the worldwide pattern of advanced economies and data based social orders where simple access to inconceivable measures of digitized data has turned into the standard. Creating nations have perceived the need to satisfy overall advancements and in addition to enhance theirgovernment performance.Many of previous academic and governmental studies have focused to study and investigate the factors behind the intention to use of egovernment over the world even in developing countries. However, this research will be quite distinguished due to some reasons. Firstly, it will examine the intention to use e- 
government instead of the adoption of e-government. Secondly, it will examine the intention to specify the employee's adoption excluding the government as I have mentioned in the introduction. The research concernsonly on the demand side of employees to have intention to use e-government.

There are numerous theories that aim to explain individual use of new technology such as Unified Theory Acceptance and Use of Technology (UTAUT), the Theory of Planed Behavior (TPB)the Theory of Reasoned Action (TRA) and Technology Acceptance Model (TAM) which, in the end, has been developed to be (TAM2).Furthermore, studies concerning about many factors such as the study which has taken place in Bahrain where the independent variables were trust, awareness and culture(Meftah, 2015). Davis (1989a)Technology Acceptance Model (TAM) is commonly used to study user's adoption of new project of information systems. TAM has two main constructs: perceived usefulness (PU) and perceived ease of use (PEOU) which influences the intention to use a system. Perceived usefulness was theoretically defined by Davis as the belief that using a particular system would enhance one's working performance. Perceived ease of use refers to one's perceptions of the amount of effort required to use the system. The model of most previous studies predicts that higher perceptions of usefulness and ease of use will increase the use of the system.

\section{LITERATURE REVIEW \& HYPOTHESIS}

Technology Acceptance Model (TAM). This modelis relatively similar to the other information systemsmodels which also concern about the factors that affect the acceptance of a new information system. The older form of this model was established by Fred Davis in his doctoral program by stating that the system use is totally influenced by the motivation of the user while the recent one got influenced by an external stimulus (Davis, 1985).

Davis has recognized that the motivation of users can be affected by three certain variables which are perceived usefulness, perceived ease of use and attitude toward using the system. However, Davis (1993) offered that the perceived usefulness could have a direct influence on the use of system without the need to have the attitude construct as an intervening variable in order to have an effect on the use of the system. This direct influence was explained by eliminating the attitude construct and introducing the behavioral intention construct (Venkatesh, 1996).

Davis (2000) added an important extension to the technology acceptance model (TAM) and identified that there might be some variables added to the perceived usefulness as antecedents which in the end called (TAM 2). There were two independent variables established from this theory to be a part of the current research model.They are the perceived usefulness and the perceived ease of use.

\section{Unified Theory of Acceptance and Use of Technology (UTAUT).}

As we live in the developed world and technology grows up day by day, we have to capture the development to survive and to ensure our existence (Carrol, 1995). Therefore, we have to adopt the new information technology which is interpreted by around eight theories, where, the Unified Theory of Acceptance and Use of Technology (UTAUT) is one of which has a great demonstration about the acceptance of the system use. The Unified Theory of Acceptance and Use of Technology (UTAUT) established 
by Venkatesh (2003) concerns about the main four components; performance expectancy, effort expectancy, social influence and facilitating conditions towards the effect on the adoption of the information technology. In addition, there are demographic characteristics functioned as moderating variables which could effect on the relationship between the independent variables and the dependent one. Nevertheless, the model of this theory has been applied in many previous studies. The findings were the up and down of the acceptance level.A research, taken in a hospital to examine the adoption of medical teleconferencing by the nurses, found that the social influence is the lowest predictor of the adoption of a new information technology (Biemans, 2005).

The concept of e-Government by Hassan (2014) investigated the adoption of EFiling by the American tax payers. Findings from this study offered that social influence and performance expectancy predict behavioral intention. Interestingly, this study considers that effort expectancy is not a predictor of behavioral intention. The inconsistency in the results of the studies on UTAUT leaves the output of the relationships in the inconclusive model.

This theory includes around four salient predictor independent variables; three of which have a direct relationship with the intention to use system (performance expectancy, effort expectancy and social influence) and the facilitating conditions having an indirect relationship with the intention to use system. In addition to the demographic characteristics, where there are two demographics have been established in the research model which are age and experience as moderating variables in order to explore their effect on the direct relationship between the latent independent variables and the dependent variable as shown in the following figure of the research model:

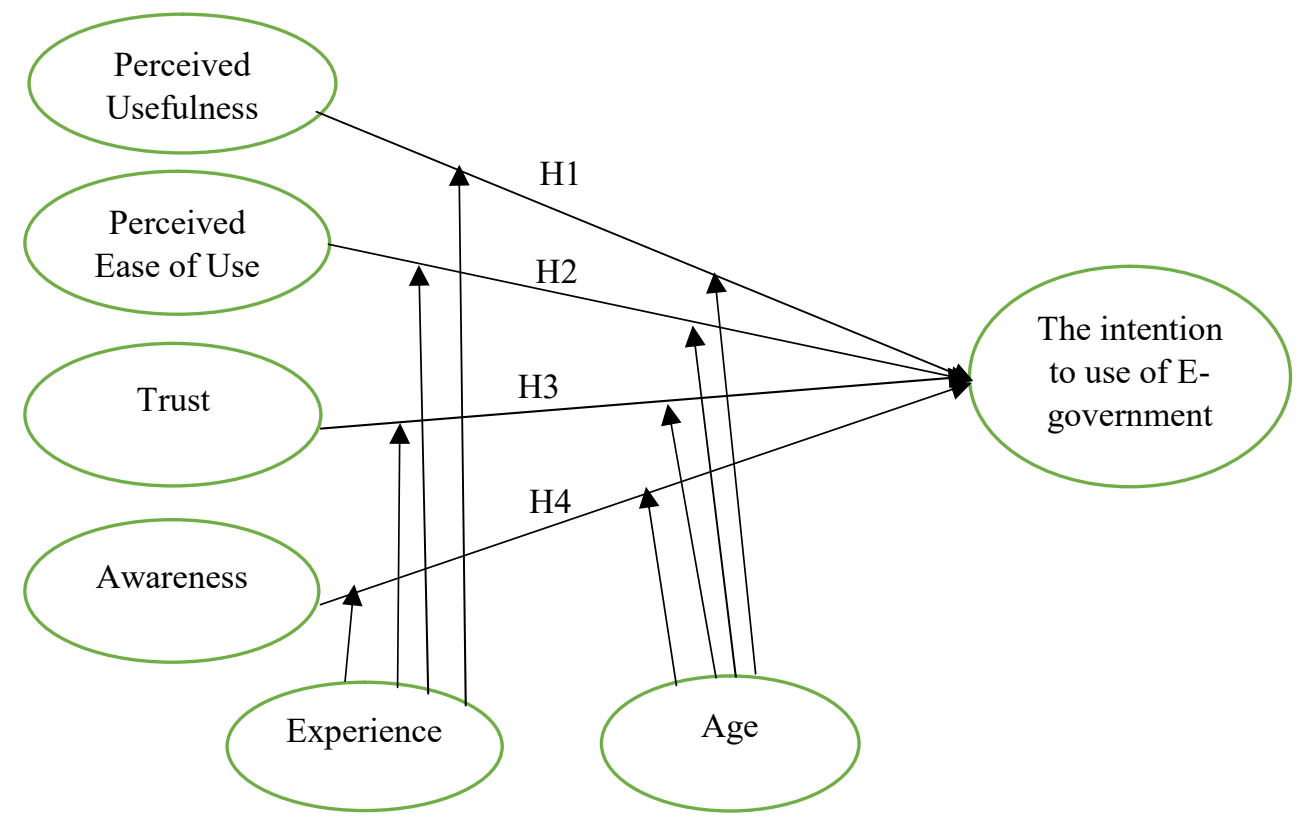

Figure (1) Research Model 


\section{Intention to Use E-government.}

The topic of e-government is relatively new for researches in this area have focused upon the demand side such as using the e-government as a tool to be connected with government 24 hours in order to fulfill the society demand in every single moment (Cottam, 2004) and evaluation of the usability of e-government websites (Alsuwaidi, 2009). However, the most attention has been given to the demand or employees perspective. Recent studies that addressed the employee intention to use e-government services suggest that trust is the major issue for e-government intention.

The intention to use e-Government has become an important topic that many researchers were interested to study and conduct a research on, even though it was proven that it is one of the most challenging issues in information technology research. There are many different studies on the intention to use of e-Government by employees conducted and each has different results and findings. However, most of them agreed that the demand for e-Government services was very low, which motivated them to identify the factors that influence the citizens' intention to use e-Government.

Some findings about UTAUT model are split into non-significant and significant factors. The non-significant factor is social influence that did not have any effect on behavioral intention for e-government service usage. The significant factors were effort expectancy, performance expectations, service conditions, and internet experience. Finally, they identified that age and gender (demographic characteristic) have no direct effect towards citizen's behavior to e-government service acceptance.

\section{Perceived Usefulness.}

Many studies have confirmed that perceived usefulness is very important to predict one's behavior. In the context of Davis (1989a)definition, perceived usefulness is defined as the degree by which the citizen believes that the website would provide all the required information. He has operationalized perceived usefulness as the extent to which the work can be done more quickly, enhancement in job performance, and an increase in productivity and effectiveness. The level of perceived usefulness directly affects e-Government intention. The website content could also be added to the perceived usefulness. Glazer (1991) suggested that the content of the website plays an important role in the satisfaction of the visitors, because if visitors fail to find what they are looking for they may not revisit the site. An incorporated e-Government entrance could be one noteworthy vehicle to achieve convenience. Rather than going to various government department sites for unmistakable errands and administrations, without having the need to know which division is in charge of what administration, citizen could go to one purpose of access for all taxpayer supported by organizations. This particular element could significantly reduce the time and effort invested in receiving information and services from the government (Government On-Line, 2003). There are principally two levels of coordination. The main, even mix(Accenture, 2004)is the combination crosswise over various offices inside every level of government - elected, common, and metropolitan. The second, vertical reconciliation(Accenture, 2004)is the coordination crosswise over various purviews of the administration. This implies the plainly recognizable lines between elected, common, and city governments today which could be missed in the digital world. Level combination crosswise over offices inside the same government is not completely accomplished yet because of either specialized or 
hierarchical reasons(Accenture, 2004).It is moderately less difficult to achieve. Vertical reconciliation crosswise over governments requires solid political will and responsibility for separating boundaries. Different controlling authorities and differences in legislation and organizational cultures lead to lack of cooperation and serve as very strong barriers (Accenture, 2004). Nevertheless, vertical integration is the only truly seamless approach to e-Government. In fact, there are many studies, which have been reviewed, have investigated this independent variable and the findings were ensured that this variable has an efficient impact on the intention to use information system (Balraj, 2014; Davis, 1989b; Gefen, 2000; Hung, 2009; Jin, 2010), Where this independent variable has been taken from the TAM's model. Thus, in this research I can formulate and develop my hypothesis of the perceived usefulness as shown below:

H1: the perceived usefulness has a positive influence on the intention to use of Egovernment system.

H1.a:the age can increase the relationship between the perceived usefulness and the intention to use of E-government system.

H1.b: the experience can increase the relationship between the perceived usefulness and the intention to use of E-government system.

\section{Perceived ease of use}

A study has been conducted by Davis(2000) has found a positive correlation between perceived ease of use and system intention. Perceived ease of use positively affects intention if the website is visited only to get information. However, in case the website is used for transaction purposes, the perceived ease of use might not affect the rate of adoption (Gefen, 2000). Personalization of websites, customization of product offerings, and self-care are the three key features that could be used not only to build relationship with the visitors, but also to enhance their experience. Roehm(1999) indicated that these features give visitors a sense of control and participation and could potentially enhance their intention. In addition to that there so many researches clarified the efficient correlation between the perceived ease of use and the intention to use system which are (Balraj, 2014; Davis, 1989b; Gefen, 2000; Hung, 2006). This an independent variable has been derived from TAM's model. Therefore, the hypothesis of the perceived ease of use will be formulated and developed as shown below:

H2: the perceived ease of use has a positive influence on the intention to use of egovernment system.

H2.a:the age can increase the relationship between the perceived ease of use and the intention to use E-government system.

H2.b:the experience can increase the relationship between the perceived ease of use and the intention to use E-government system.

\section{Trust}

The trust of the clients (employees) is completely diminished in the web based shopping environment for absence of up close and personal connection between both purchaser and customer and buyer and item (Cho, 2007). Trust in online situations surpasses the basic importance of trust to incorporate trust in actually or socially dynamic frameworks (Sydow, 1998). The idea of trust framework in online situations is 
based upon faith in the bent of the standards relating to individual communication as well as extracting frameworks(Sydow, 1998).

Online clients not only seek about having trust online vendor, but they also wary about having trust of the Web itself as a transaction medium(McKnight, 2001). Therefore, Rea (2001) proposed that expanding the familiarity with how to actualize framework plans that endeavor the client's semantic comprehension of electronic business process can be a useful method in building trust in electronic situations. LikewiseZuboff(1988)in her study focusing on information technology intention to use found that the lack of trust in a new technology would affect its intention to use. Actually, trust is an important factor influencing consumer behavior and it determines the success of technologies such as e-Commerce (Holsapple,2005).According toPalvia(2009), trust has a significant effect on participation intention through usage attitude. In the context of B2C e-Commerce, building trust between two parties is crucial for companies deciding to do business online (Al-Ghaith, 2010). Several studies found that consumers' trust is significantly related to trust in the e-Commerce Web site itself, and perceived site quality is positively related to trust in the Web site (Al-Ghaith, 2010). According to the findings and understanding of the background on the influence of trust on e-government system I can formulate and develop my hypothesis to be as shown.

H3: the trust has a positive influence on the intention to use of e-government system.

H3.a:the age can increase the relationship between the trust and the intention to use Egovernment system.

H3.b:the experience can increase the relationship between the trust and the intention to use E-government system.

\section{Awareness}

Attention to e-Government alludes all the will scope from claiming learning and recognition of human need through e-Government benefits. An extensive variety of investigations might have been led in regards to the Components Also issues that influence citizens' consciousness around e-Government. Administrations are also a significant number of other investigations proposing a few methodologies on the increment of citizens' consciousness at e-Government administrations. Choudrie(2005a)studied the citizens' awareness on e-Government initiatives in the UK. He found that there are several factors that have a significant influence on e-Government awareness. They are age, gender, education, social class, income and broadband access of internet. The study indicated that when increases in the citizens' age ranges occurred, there was more awareness of the Government gateway. Also, it revealed that males are more aware of e-Government services than females. The majority of citizens who are aware of e-Government services are educated no matter the degree level is. Residents who have a place with social class "E" are more mindful of online administrations. The author proposed that the awareness and selection of e-taxpayer supported organization diminishes as the social class of respondents decreases. In addition, the study illustrates that almost all income segments are aware of the government gateway. They also found that citizens with home broadband access are more likely to adopt e-Government services. 
According to Dourish(1992),awareness is "an understanding of the activities of others which provides a context for your own activity". Consciousness incorporates the utilization of broad communications by presenting the idea about E-government framework for people in the government funding sectors, andby directing seminars or workshops on people in general sectors who fill in compel to apply the ideas concerning with the illustration of their Everyday operations. A package of activities could be delivered that includes (Heeks, 2001)seminars and training workshops, web-based documentation, individual meetings, and support for monitoring and project evaluation. There are studies reflected the significant impact of the awareness on the intention to use a system such as (Charbaji, 2003; Choudrie, 2005b; Jung, 2012; Leonard, 2004; Siponen, 2000). In addition to those previous studies also there were a study, which has been conducted recently, informed that the awareness has a significant impact on the intention to use e-government (Meftah, 2015). Hence this an independent variable has been derived from previous study has performed in Bahrain. Lastly, I propose and formulate the hypothesis as shown below:

H4: the awareness has a positive influence on the intention to use of e-government system.

H4.a: the age can increase the relationship between the Awareness and the intention to use of E-government system.

H4.b: the experience can increase the relationship between the awareness and the intention to use E-government system.

\section{METHODOLOGY}

It is clearly known that the samples are just only certain numbers which have been derived or calculated from the population as a certain data to be analyzed to have background about the relationship between the independent and dependent variables. In addition, as the sample size is huge, the reliability of results is high. Furthermore, focusing on the suitable size of the sample is extremely important for getting a reliable and valid sample in order to obtain a great result from the analysis of the data to have reasonable outcome to answer the research questions. For instance, the way of choosing sample data named as census method (the sample size equal to the population size), where, The primary data have been collected by using questionnaire surveys distributed over 110 finance and admission employees and the real respondents were just 86 respondents.

After collecting the data by using questionnaire (quantitative data), they were analyzed using statistical tool named Partial Least Square (PLS).It is included in the square equation model (SEM) in order to have a great explanation about the predictive relationship between the independent variables and dependent variable.

Validity has the capacity to explain the ability to measure what can be measured. Therefore, it tries to show how the homogenous between the instruments and items by comparing the correlation between the index of Pearson Product Moment with alpha level. For instance, the correlation between instruments and items should be less than alpha, otherwise it is invalid ( $\alpha$ bigger than 0.05). However, all instruments are individually valid as shown in the appendix (A).

The reliability is conducted through 30 respondents of Libyan student in Malang. The purpose of the reliability is just to consider the correlation between the 
instruments and the statements. On the other hand, it aims to recognize if the measurement is reliable. The reliability is measured by comparing it with the Cronbach Alpha which has been set to be at0.70 (more than 0.70 is reliable). However, all variables which included in this research were reliable where the Cronbach Alpha was more than 0.70 as shown in the appendix (B). For instance, the statistical formula (Equation) is shown below:

$$
\begin{aligned}
& \mathrm{Y} 1=\beta 1 \mathrm{X} 1+\beta 2 \mathrm{X} 2+\beta 3 \mathrm{X} 3+\beta 4 \mathrm{X} 4+\beta 5 \mathrm{Z} 1+\beta 6 \mathrm{Z} 2+\beta 7 \mathrm{X} 1 \mathrm{Z} 1+\beta 8 \mathrm{X} 2 \mathrm{Z} 1+\beta 9 \mathrm{X} 3 \\
& \mathrm{Z} 1+\beta 10 \mathrm{X} 4 \mathrm{Z} 1+\beta 11 \mathrm{X} 1 \mathrm{Z} 2+\beta 12 \mathrm{X} 2 \mathrm{Z} 2+\beta 13 \mathrm{X} 3 \mathrm{Z} 2+\beta 14 \mathrm{X} 4 \mathrm{Z} 2+\mathrm{e}
\end{aligned}
$$

Where:

$\mathrm{Y} 1=$ Intention to use (INT)

$\mathrm{X} 1=$ Perceived usefulness

$\beta=$ Coefficient

$\mathrm{X} 2=$ Perceived ease of use

$\mathrm{e}=$ Error

$\mathrm{X} 3=$ Trust

$\mathrm{Z1}=$ Moderating variable (Age)

$\mathrm{X} 4=$ Awareness

$\mathrm{Z} 2$ = Moderating variable (Experience)

\section{FINDING AND DISCUSSIONS}

\section{Demographic Characteristics}

This pattern presents personal characteristics of the respondents such as gender, age, education level and experience as shown in table (1) and table (2). These sections of the demographic characteristic can be explained by using descriptive statistic tool in order to know the frequency and the percentage of every single section of the employees who use E-government system. In addition, most respondents were male (79), and only (7) respondents were female.

Table (1) Frequency Analysis

\begin{tabular}{|c|c|c|c|}
\hline Demography & Classification & Frequency & Percentage \\
\hline Gender & Male & 79 & $91.9 \%$ \\
& Female & 7 & $8.1 \%$ \\
\hline \multirow{2}{*}{ Education } & High school & 10 & $11.6 \%$ \\
& College degree & 8 & $9.3 \%$ \\
& Bachelor degree & 61 & $70.9 \%$ \\
& Postgraduate degree & 7 & $8.1 \%$ \\
\hline
\end{tabular}


Table (2) Descriptive Analysis

\begin{tabular}{|c|r|r|r|r|}
\hline Demography & \multicolumn{1}{|c|}{ Minimum } & \multicolumn{1}{c|}{ Maximum } & \multicolumn{1}{c|}{ Mean } & \multicolumn{1}{c|}{ Std. Deviation } \\
\hline Age & 25.00 & 53.00 & 35.4884 & 5.70190 \\
\hline Experience (1) & $24.00^{*}$ & $240.00^{*}$ & $102.0349^{*}$ & 50.64884 \\
\hline Experience (2) & $.00^{* *}$ & $10.00^{* *}$ & $1.4186^{* *}$ & 2.07203 \\
\hline
\end{tabular}

$*=$ Number of Months of using the computer, $* *=$ How many times you buy per year using online shopping.

Gender. This section actually concerns about the number of male or females who pay a strong intention to use E-government system through the employees in a shipping and exporting company. After having the frequency analysis in the SPSS software, it is found that $91.9 \%$ of males who pay intention to use E-government system and the other $8.1 \%$ were female employees. Therefore, we can recognize that the male employees are more than the female ones. However, it does not mean that females avoid implementing the E-government system, because it could be related to the less chance to be an employee in such company and the following figure shows the bar chart of the frequency of the gender section.

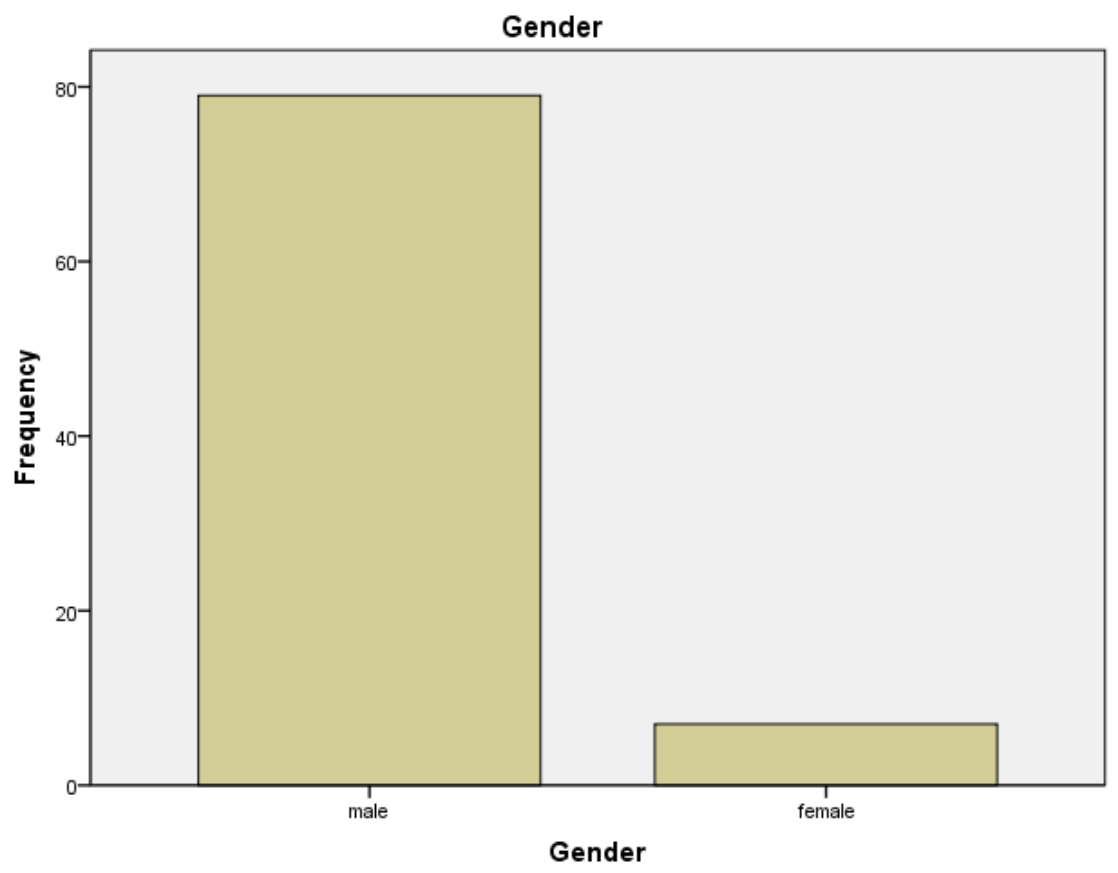

Figure (2) The Bar Chart of Gender Section 
Education Level. In this part, it is clearly noticed that the majority of employees hold bachelor degree. They are around 61 employees, which means about 70.9\%. 10 employees hold high school which is around $11.6 \% .8$ employees hold college degree which is around $9.3 \%$, and the other 7 which are around $8.1 \%$ hold postgraduate degree. However, in my opinion, I can say that the lack of having employees with postgraduate degree could be a reason of the lack of the implementation of E-government system. The following figure will show the frequency of the education level of the employees.

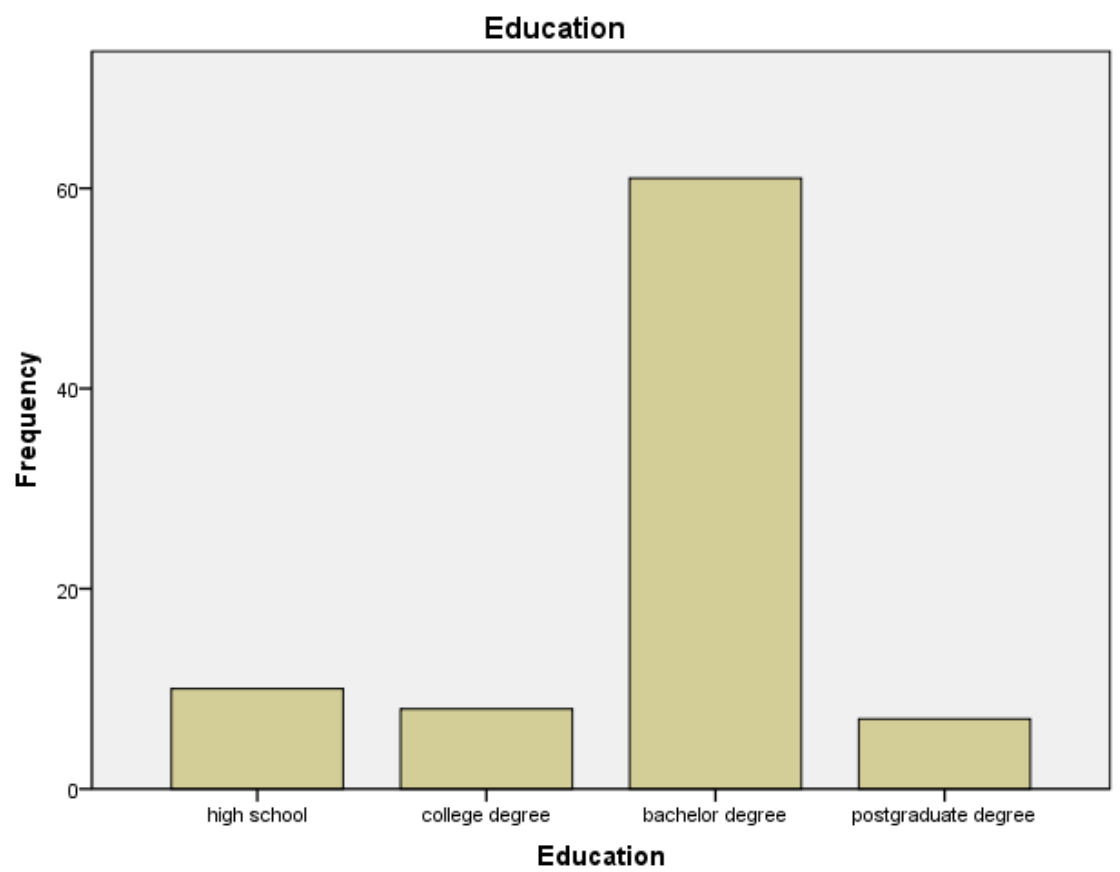

Figure (3) The Education Level Section

Age. This section provide the age of every employee by using ratio measurement. The age as a demographic characteristic has been used as a moderating variable to see if it influences the relationship between the independent variables and the dependent variable. It shows that the minimum age was 25 years and the maximum one was 53 years. The mean was around $35.4884+/-5.70190$.

Experience. According to this term, I have divided experience into two stages where, the first stage (Exp1) only shows how many months the employee has been using the computer. It appeared with 24 months as minimum and 240 months as a maximum. The mean was around $102.0349+/-50.64884$ months. The second stage (Exp2) shows how many times every single employee do online shopping per year. It also appears with zero as minimum and 10 times a year as a maximum. The mean was about $1.4186+/$ 2.07203. However, the experience of shopping online (Exp2) has been chosen relatively 
to be a moderating variable because it measures the personal inclinations to deal with the electronic program.

\section{Evaluation Model (Outer Model)}

The pattern of evaluation model concerns about the convergent validity by comparing the outcome with $50 \%$, if the amount of the outcome is bigger than $50 \%$, it means valid. The result is shown in the following table:

\section{Table (3) Outer Loading Value}

\begin{tabular}{|c|c|c|c|}
\hline Variable & Indicator & Outer Loading & Result \\
\hline \multirow{3}{*}{ Perceived Usefulness } & $\mathrm{X} 1.1$ & 0.607574 & Valid \\
\hline & $\mathrm{X} 1.2$ & 0.856068 & Valid \\
\hline & $\mathrm{X} 1.3$ & 0.756239 & Valid \\
\hline \multirow{2}{*}{$(\mathrm{X} 1)$} & X1.4 & 0.830872 & Valid \\
\hline & $\mathrm{X} 1.5$ & 0.792613 & Valid \\
\hline \multirow{3}{*}{$\begin{array}{l}\text { Perceived Ease of Use } \\
\qquad \text { (X2) }\end{array}$} & $\mathrm{X} 2.1$ & 0.778599 & Valid \\
\hline & $\mathrm{X} 2.2$ & 0.818403 & Valid \\
\hline & $\mathrm{X} 2.3$ & 0.888399 & Valid \\
\hline \multirow{5}{*}{$\begin{array}{l}\text { Trust } \\
\text { (X3) }\end{array}$} & X3.1 & 0.59067 & Valid \\
\hline & $\mathrm{X} 3.2$ & 0.597555 & Valid \\
\hline & X3.3 & 0.806137 & Valid \\
\hline & X3.4 & 0.841198 & Valid \\
\hline & X3.5 & 0.766502 & Valid \\
\hline \multirow{5}{*}{ Awareness } & $\mathrm{X} 4.1$ & 0.775558 & Valid \\
\hline & $\mathrm{X} 4.2$ & 0.800754 & Valid \\
\hline & $\mathrm{X} 4.3$ & 0.63109 & Valid \\
\hline & $\mathrm{X} 4.4$ & 0.563608 & Valid \\
\hline & $\mathrm{X} 4.5$ & 0.718587 & Valid \\
\hline \multirow{2}{*}{$\begin{array}{l}\text { Intention to Use } \\
\text { (Y1) }\end{array}$} & Y1.1 & 0.925708 & Valid \\
\hline & Y1.2 & 0.673588 & Valid \\
\hline
\end{tabular}


Discriminant validity explains the validity of every single variable included in the research model. The measurement can be conducted by finding out the square root of AVE and comparing it with 50\% (comparison value). If the value is higher than 50 $\%$,it means valid. The following table shows the discriminant validity:

Table (4) Average Variance Extracted (AVE) Results

\begin{tabular}{|c|c|c|c|c|c|}
\hline Variables & AVE & $\begin{array}{c}\text { Composite } \\
\text { Reliability }\end{array}$ & R Square & $\begin{array}{c}\text { Cronbachs } \\
\text { Alpha }\end{array}$ & $\begin{array}{c}\text { Square root } \\
\text { of AVE }\end{array}$ \\
\hline PU & 0.598496 & 0.880355 & & 0.84648 & 0.773625 \\
\hline PEU & 0.688418 & 0.868567 & & 0.779017 & 0.82971 \\
\hline Trust & 0.530192 & 0.846707 & & 0.790329 & 0.728143 \\
\hline Awareness & 0.494999 & 0.828258 & & 0.743589 & 0.703562 \\
\hline INT & 0.655328 & 0.787704 & 0.399832 & 0.511891 & 0.809523 \\
\hline
\end{tabular}

According to the table (4),it is clearly shown that the square root of Perceived Usefulness is approximately 0.773 , Perceived Ease of Use is 0.829 , Trust is 0.728 , Awareness is 0.703 and Intention to use is about 0.809 . The square root of Average Variance Extracted is higher than 50\% for all variables included in the research model.

Reliability only concerns about determinant whether those latent independent and dependent variables in the research model are reliable or not by comparing composite reliability with the measurement of the reliability (Cronbach's Alpha).It is 70 $\%$ as shown in the table (4), where the Perceived Usefulness is 0.880, Perceived Ease of Use is 0868 , Trust is 0.846 , Awareness is 0.828 and Intention to Use is about 0.787. It means all the composite reliability is greater than 0.70 . Thus, it is very clear to state that the current research model is reliable.

\section{Evaluation Structural Model (Inner Model)}

It ensures that the research model, whether discriminant or convergent as well as the reliability according to the composite reliability, is valid. For instance, in this pattern we just focus on the relationship between the independent and dependent variables by looking at the R-square as it has been mentioned in the table (4), which is approximately 0.399.It means all independent variables in the current research model can explain the dependent variable (Intention to Use) at $39.9 \%$ and the other $60.1 \%$ can be explained by other independent variables excluding this research model

Testing hypothesis can be recognized by using the statistical tests. Specifically, it is enacted by focusing on the t-value and comparing it with the 1.645 because it is only one-tail. Because there is a moderating variable (Age), we should show the results 
before adding the moderating variable,and then we can compare the two situations. The next figure will show the research model form before adding the moderating variable:

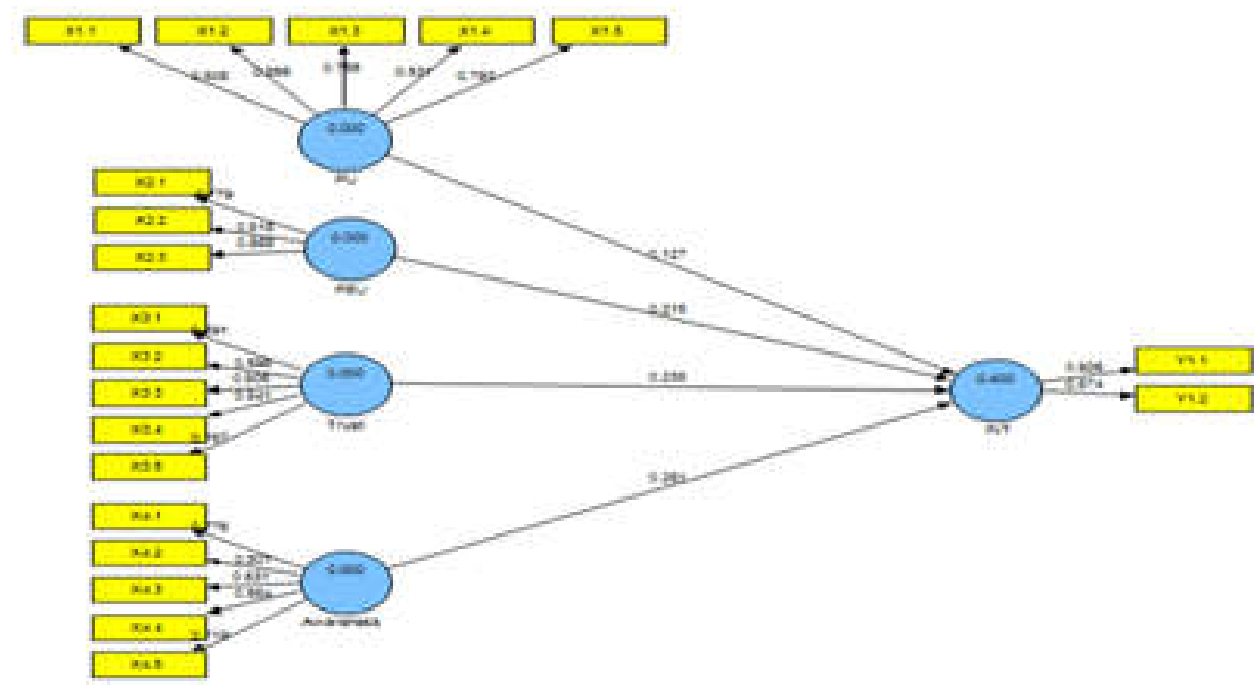

Figure (4) Conceptual Model: The Impact of Independent Variableson the Intenstion to Use E-government Systme before Adding the Moderating Variable.

Table (5)Testing Hypothesis Results Before Adding The Moderating Variable

\begin{tabular}{|c|c|c|c|c|}
\hline Hypothesis & Variables & $\begin{array}{c}\text { Original } \\
\text { Sample (O) }\end{array}$ & $\begin{array}{c}\text { T Statistics } \\
(\mid \text { O/STERR } \mid)\end{array}$ & Results \\
\hline H1 & PU -> INT & 0.127057 & 1.045615 & Rejected \\
\hline H2 & PEU -> INT & 0.215458 & 1.726943 & Supported \\
\hline H3 & Trust -> INT & 0.237506 & 2.749941 & Supported \\
\hline H4 & $\begin{array}{c}\text { Awareness -> } \\
\text { INT }\end{array}$ & 0.25081 & 2.102016 & Supported \\
\hline
\end{tabular}

Based on the table (5) which shows the hypothesis results before adding the moderating variables, we can recognize that the hypothesis (H1) which tested the relationship between the Perceived Usefulness and the Intention to use E-government system is rejected (the perceived usefulness has a positive influence on the intention to use -government system).Thus, the Perceived usefulness does not have influence on the Intention to use E-government system. The coefficient path indicated that there is no impact between the previous variables as shown in the table (5) in the original sample 
column. The hypothesis (H2) which examining the relationship between the Perceived Ease of Use and the Intention to use E-government system is supported (the perceived ease of use has a positive influence on the intention to use of e-government system).Furthermore, the Perceived Ease of Use has an influence on the Intention to use E-government and also the coefficient path indicated that there is an impact between the two variables. The hypothesis (H3)examining the relationship between Trust and Intention to use E-government system also resulted positively (the trust has a positive influence on the intention to use e-government system). Thus, the Trust construct has an influence on the Intention to use E-government system, where the coefficient path shows that there is an impact on the intention to use E-government system by the Trust construct. The hypothesis (H4)which explains the relationship between the Awareness and Intention to use E-government system is supported as well (the awareness has a positive influence on the intention to use of e-government system). Therefore, the Awareness construct has an influence on the Intention to use E-government system, wherethe coefficient path also shows that there is an impact on the intention to use by Awareness.

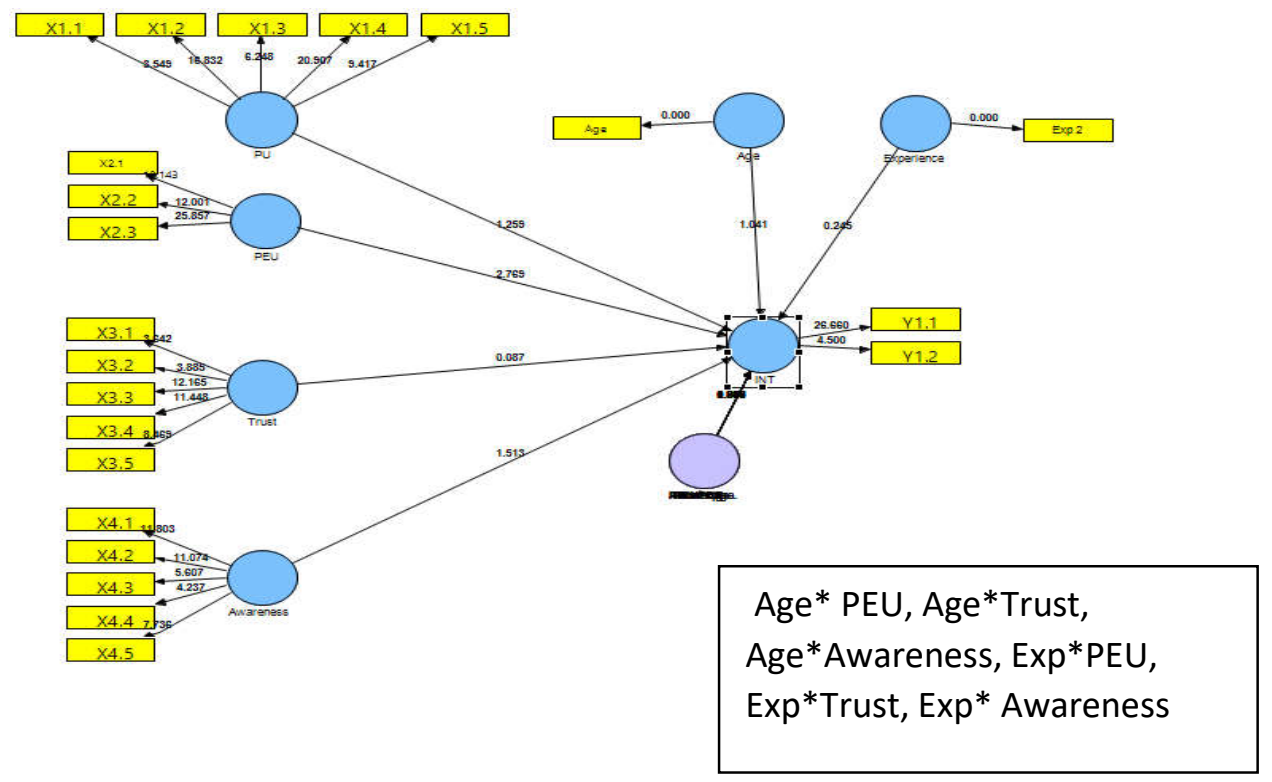

Figure (5) Conceptual Model: The Impact of Independent Variablesto Intenstion to UseE-government Systemafter Adding the Moderating Variable. 
Table (6)Testing Hypothesis Resultsafter Adding the Moderating (Age)

\begin{tabular}{|c|c|c|c|c|}
\hline Hypothesis & Variables & $\begin{array}{c}\text { Original } \\
\text { Sample }(0)\end{array}$ & $\begin{array}{l}\text { T Statistics } \\
\text { (|O/STERR|) }\end{array}$ & Results \\
\hline & Age $->$ INT & -0.716964 & 0.17182 & \\
\hline & Experience -> INT & 0.265605 & 0.244627 & \\
\hline H1 & PU -> INT & - & - & Not tested \\
\hline H1.a & PU * Age -> INT & - & - & Not tested \\
\hline H1.b & $\begin{array}{c}\mathrm{PU} * \text { Experience }-> \\
\text { INT }\end{array}$ & - & - & Not tested \\
\hline H2 & PEU -> INT & -2.066447 & 2.768536 & Supported \\
\hline H2.a & PEU * Age -> INT & 2.727901 & 2.689353 & Supported \\
\hline H2.b & $\begin{array}{c}\text { PEU * Experience -> } \\
\text { INT }\end{array}$ & 1.455392 & 1.791234 & Supported \\
\hline H3 & Trust -> INT & -0.055955 & 0.0866 & Rejected \\
\hline H3.a & Trust * Age $->$ INT & 0.216177 & 0.268979 & Rejected \\
\hline H3.b & $\begin{array}{c}\text { Trust * Experience - } \\
\text { > INT }\end{array}$ & 1.224558 & 1.557412 & Rejected \\
\hline H4 & Awareness -> INT & 0.994438 & 1.512959 & Rejected \\
\hline H4.a & $\begin{array}{c}\text { Awareness * Age -> } \\
\text { INT }\end{array}$ & -0.691374 & 0.982119 & Rejected \\
\hline H4.b & $\begin{array}{c}\text { Awareness * } \\
\text { Experience -> INT }\end{array}$ & -0.482094 & 0.847639 & Rejected \\
\hline
\end{tabular}

According to the previous table (6), the hypothesis (H1.a)which explains if the Age can increase the relationship between the Perceived Usefulness and the Intention to use E-government system(the age can increase the relationship between the perceived usefulness and the intention to use E-government system.)and the hypothesis (H1.b)which says (the experience can increase the relationship between the perceived usefulness and the intention to use E-government system) basically, have not been 
tested because of rejecting the hypothesis (H1). The hypothesis (H2.a) examining the increasing the relationship between the Perceived Ease of Use with the Intention to use E-government system (the age can increase the relationship between the perceived ease of use and the intention to use E-government system). Therefore, it increased the relationship of both variables. So, the hypothesis is accepted (Supported) forthe Tstatistic is around 2.689 which is greater than 1.645. The hypothesis (H2.b)says (the experience can increase the relationship between the perceived ease of use and the intention to use E-government system). It shows that the experience increased the relationship between the perceived ease of use and the intention to use e-government system. It means that this hypothesis is supported. The hypothesis (H3.a) explains that Age increases the relationship between the Trust and the Intention to use E-government system (the age can increase the relationship between the trust and the intention to use E-government system). Age could not increase the relationship of the trust and the intention to use E-government system.It means that this hypothesis is rejected. The hypothesis (H3.b) which says (the experience can increase the relationship between the trust and the intention to use E-government system)is also rejected, because the experience does not increase the relationship of the trust and the intention to use. However, both age and experience effected on the direct relationship between the trust and intention to use to be rejected as well. The hypothesis (H4.a) explains that age increases the relationship between the Awareness and Intention to use E-government system (the age can increase the relationship between the Awareness and the intention to use of E-government system). The Age could not increase the relationship between them, which means this hypothesis is also rejected. The hypothesis (H4.b) says (the experience can increase the relationship between the awareness and the intention to use E-government system). It shows that the experience does not have an influence on the relationship between the awareness and the intention to use which means this hypothesis has been rejected too. Both of them (age and experience) effected on the direct relationship between the awareness and intention to use to be rejected.

\section{DISCUSSION RESULT}

This study has been conducted by having an explanation and analyses on the research questions. After testing the hypothesis through PLS tool,resulting on whether it was supported or rejected, the statements related to the influence of independent variables on the dependent variable would be further discussed individually and compared with the other previous studies.

\section{Perceived Usefulness to the Intention to Use E-government System}

There are such studies have confirmed the perceived of usefulness is very important for predicting a person's behavior. In the context of Davis (1989a)definition, perceived usefulness is defined as the degree to which the citizen believes that the website would provide all the required information. He has operational zed perceived usefulness as the extent to which the work can be done more quickly, an enhancement in job performance, and an increase in productivity and effectiveness. But according to the current study the hypothesis of perceived usefulness which says that the perceived usefulness has an influence on the intention to use E-government has been rejected. In 
other words, the perceived usefulness does not have an influence on the intention to use E-government. However, this situation would guide us to think about the cause of rejecting this hypothesis which it could be the services that delivered by the government to the employees is not at the accepted level and it could also be the way of establishing the web site and facing such error through processing the transactions. For instance, the young age could have no interested in using new technologies in processing government services, even their experience of shopping online is at a low level which is not more than twice annually. Thus, the most of employees look at the E-government as useful new technology.

\section{Perceived Ease of Use to Intention to Use E-government System}

A study has conducted by Davis (2000) found a positive correlation between perceived ease of use and system adoption. Perceived ease of use positively affects adoption if the website is visited only to get information, but if the website is used for transaction purposes then the perceived ease of use might not affect the rate of adoption (Gefen, 2000). By focusing in many previous studies findings that most of them even all of them showed that there is a significant effect on the intention to use of e-government (Lean, 2009). In addition to that in the same study of Hung (2006) in Taiwan where he found that there is a significant impact of perceived ease of use on the intention to use of e-government. Based on the current study, the perceived ease of use has an influence on the intention to use E-government system where that has been shown through the hypothesis (H2). It is agreed the previous studies, where those previous studies have explained that the perceived ease of use can effect on the intention to use and also after adding the age and the experience as moderating variables the situation is still the same.

\section{Trust to Intention to Use E-government System}

Lean (2009) stated that users will obtain and improve their trust and support it strongly when they believe the website is moral and legal, ethical (especially in Islamic countries), full of trust and is able to safeguard their Secrecy.. The trust can also be defined as quantified reliance by a trust or respect towards the ability, trustworthiness, security and reliability of a trustee within a specified context. More often than seldom all of the studies carried out indicate that trust is the main factor that contributes the employees trust on e-Government success. Nevertheless, the most previous academic studies indicated that the trust can effect on the intention to use and also in the current research the hypothesis (H3) has been supported which means the trust has an influence on the intention to use E-government system, but after adding the moderating variables it converted to be rejected. Thus, the both moderating variables have affected on the direct relationship and that it could be related to such bad experience of the employees through processing such transactions or there are so many advertisement coming up when they try to operate such transactions which make them with less trust. And because the mean of age is around 35 years, it could also be a reason of less trust of the employees where there are many studies showed that the trust has a linear relationship with the age. In addition, it could be due to entrust of the web site itself which delivers the E-government system. 


\section{Awareness to Intention to Use E-government System}

In brief, we can say the awareness play an important role for improving the intention of employees in order to use the e-government project and actually, there are studies reflected the significant impact of the awareness on the intention to use a system such as (Jung, 2012). In addition to those previous studies also there were a study, which has been conducted recently, informed that the awareness has a significant impact on the intention to use e-government (Meftah, 2015). This variable has defined as having a knowledge toward obtaining the understanding of the activities of others, which provides a context for your own activity (Dourish, 1992).

Relating to the current research, the awareness has an influence on the intention to use E-government system and this has been known from accepting the hypothesis (H4). But after adding the moderating variables the situation has been changed, where the direct relationship between the awareness and the intention to use started to be rejected and that could be related to the majority of young age which the last causes less experience toward be unaware of the E-government system and it also due to the early stage of implementing the new system during the Libyan companies. However, this rejecting also could be related to the weakness of the government itself for spreading the advertisement about using the E-government and explain its benefit widely over the employees by implementing such seminar, workshop and so on.

\section{CONCLUSION \& LIMITATION Conclusion}

According to the results which have been obtained from the previous chapters, we really need to pay more attention toward have full understanding about the Egovernment system through the employees. For instance, from the findings I can say that there are some obstacles that faced by the employees in implementing the E-government system. In my opinion, if we look back to the research model we can recognize that the Perceived Usefulness (PU) as an independent variable does not have an influence on the Intention to Use (INT) and that relates to no gaining benefits of E-government to the employees. The Perceived Ease of Use has an influence on the intention to use except after adding the age as a moderating variable where it converted the direct relationship between the perceived ease of use and the intention to use to be rejected. The Trust has been shown in the findings that it has an influence on the intention to use E-government system, but after adding the moderating variables the situation has been changed to be rejected. The Awareness construct during the results showed that it has an influence on the intention to use, but after adding the moderating variables the situation has also been changed to be rejected. However, the perceived usefulness could not influence the intention to use.

\section{Limitation}

This research has been conducted in Libya through employees. for instance the real reason for having this research during the employees in Libya, because the majority of developing countries suffer from the low level of acceptance a new information system project such as e-government. Forever, there are such limitations which should be taken in account as shown below: 
1. This research has relatively demonstrated the predictive relationship narrowly because of the limit time of conducting the research.

2. Conducted data by using a survey questionnaire was professionally done because I work as an accountant in the shipping and exporting company. Thus, all respondents are my colleague.

3. This research could have such important factors which missed out the research model which may inspirit extra explanation about the intention to use e-government.

4. Through conducting this research, the research model partly has expressed about the sufficient of TAM's model by accepting the perceived ease of use variable.

5. The majority of respondents were at young age and less experience. Thus, this situation could be the cause of the limitation explanation of the employee's intention to use e-government system. 


\section{REFERENCES}

Accenture, E. (2004). Government leadership: High performance, maximum value. The government executive series.

Al-Ghaith, W.et al. (2010). Factors influencing the adoption and usage of online services in Saudi Arabia. EJISDC: The Electronic Journal on Information Systems in Developing Countries(40), 1.

Alsuwaidi, H. (2009). Evaluating the Factors Affecting for the Adoption of Egovernment Services in the Public Sector (UAE). Brunel University.

Balraj, A. et al. (2014). Factors influencing consumers' behavioural intention on Ecommerce adoption in malaysia. SMART Journal of Business Management Studies, 10(2), 1-11.

Busoud, A., \&Živković, D. (2016). E-government in Libya. INTERNATIONAL SCIENTIFIC CONFERENCE ON ICT AND E-BUSINESS RELATED RESEARCH.

Charbaji, A., \& Mikdashi, T. (2003). A path analytic study of the attitude toward egovernment in Lebanon. Corporate Governance: The international journal of business in society, 3(1), 76-82.

Cho, D. et al. (2007). Analysis of trust in internet and mobile commerce adoption. Paper presented at the System Sciences, 2007. HICSS 2007. 40th Annual Hawaii International Conference on.

Choudrie, J. et al. (2005a). Citizens' awareness and adoption of e-Government initiatives in the UK, eGovernment Workshop'05 (eGOV05). Brunel University, West London, UK.

Cottam, K. (2004). A Local Government CRM Maturity Model: a component in the transformational change of UK councils. AMCIS 2004 Proceedings, 132.

Davis, F. et al. (1989a). Perceived usefulness, perceived ease of use, and user acceptance of information technology. MIS quarterly, 319-340.

Davis, F. et al. (2000). A theoretical extension of the technology acceptance model: Four longitudinal field studies. Management science, 46(2), 186-204.

Dourish, P., \& Bellotti, V. (1992). Awareness and coordination in shared workspaces. Paper presented at the Proceedings of the 1992 ACM conference on Computersupported cooperative work.

Gefen, D., \& Straub, D. (2000). The relative importance of perceived ease of use in IS adoption: A study of e-commerce adoption. Journal of the association for Information Systems, 1(1), 8.

Glazer, R. (1991). Marketing in an information-intensive environment: strategic implications of knowledge as an asset. The Journal of Marketing, 1-19.

Heeks, R. (2001). Building e-governance for development: A framework for national and donor action.

Holsapple, C., \& Sasidharan, S. (2005). The dynamics of trust in B2C e-commerce: a research model and agenda. Information Systems and e-business Management, 3(4), 377-403. 
Hung, S. et al. (2006). Determinants of user acceptance of the e-Government services: The case of online tax filing and payment system. Government Information Quarterly, 23(1), 97-122.

Hung, S. (2009). User acceptance of intergovernmental services: An example of electronic document management system. Government Information Quarterly, 26(2), 387-397.

Jin, X. et al. (2010). Predicting continuance in online communities: model development and empirical test. Behaviour \& Information Technology, 29(4), 383-394.

Jung, J. et al. (2012). Factors affecting e-book reader awareness, interest, and intention to use. new media \& society, 14(2), 204-224.

Leonard, L. et al. (2004). What influences IT ethical behavior intentions-planned behavior, reasoned action, perceived importance, or individual characteristics? Information \& Management, 42(1), 143-158.

Meftah, B. (2015). Adoption of E-Government among Bahraini Citizens. Asian Social Science,

information technology. MIS quarterly, 319-340. in the Public Sector (UAE). Brunel University.

McKnight, N. (2001). What trust means in e-commerce customer relationships: an interdisciplinary conceptual typology. International journal of electronic commerce, 6(2), 35-59.

Palvia, P. (2009). The role of trust in e-commerce relational exchange: A unified model. Information \& Management, 46(4), 213-220.

Roehm, H., \& Haugtvedt, C. (1999). Understanding interactivity of cyberspace advertising. Advertising and the world wide web, 27-39.

Riyadh, Hosam Alden, Sukoharsonom, Eko Ganis \& Baridwan Z. 2015. "E-Banking Implementation and Technology Acceptance in the Rafidain and Rasheed Banks in Iraq : An Employee Perspective."

Siponen, M. (2000). A conceptual foundation for organizational information security awareness. Information Management \& Computer Security, 8(1), 31-41.

Sydow, J. (1998). Understanding the constitution of interorganizational trust. Trust within and between organizations: Conceptual issues and empirical applications, 31-63.

Turban, E. (2004). Information Technology for Management Adapted from Information Technology for Management Transforming Organizations in the Digital Economy.

UNDP Libya, (2013), Newsletter September 2013, Retrieved February 21, 2016, from http://www. newsletter3_10_2013\%20Eng.pdf

Zuboff, S. (1988). In the age of the smart machine: The future of work and power: Basic Books. 


\section{Appendix (A)}

\begin{tabular}{|c|c|c|c|c|}
\hline Variable & Item & $\mathrm{R}$ & Sig & Exp \\
\hline \multirow{5}{*}{$\begin{array}{l}\text { Perceived Usefulness } \\
\text { (X1) }\end{array}$} & X1.1 & 0.503 & 0.000 & Valid \\
\hline & $\mathrm{X} 1.2$ & 0.818 & 0.005 & Valid \\
\hline & X1.3 & 0.749 & 0.000 & Valid \\
\hline & X1.4 & 0.702 & 0.000 & Valid \\
\hline & X1.5 & 0.671 & 0.000 & Valid \\
\hline \multirow{5}{*}{$\begin{array}{l}\text { Perceived Ease of Use } \\
\text { (X2) }\end{array}$} & X2.1 & 0.778 & 0.000 & Valid \\
\hline & $\mathrm{X} 2.2$ & 0.652 & 0.000 & Valid \\
\hline & $\mathrm{X} 2.3$ & 0.689 & 0.000 & Valid \\
\hline & X2.4 & 0.634 & 0.000 & Valid \\
\hline & X2.5 & 0.623 & 0.000 & Valid \\
\hline \multirow{5}{*}{$\begin{array}{l}\text { Trust } \\
\text { (X3) }\end{array}$} & X3.1 & 0.625 & 0.000 & Valid \\
\hline & X3.2 & 0.677 & 0.000 & Valid \\
\hline & X3.3 & 0.752 & 0.000 & Valid \\
\hline & X3.4 & 0.864 & 0.000 & Valid \\
\hline & $\mathrm{X} 3.5$ & 0.774 & 0.000 & Valid \\
\hline \multirow{5}{*}{ (X4) } & X4.1 & 0.784 & 0.000 & Valid \\
\hline & $\mathrm{X} 4.2$ & 0.821 & 0.000 & Valid \\
\hline & $\mathrm{X} 4.3$ & 0.450 & 0.000 & Valid \\
\hline & X4.4 & 0.619 & 0.000 & Valid \\
\hline & $\mathrm{X} 4.5$ & 0.444 & 0.000 & Valid \\
\hline \multirow{3}{*}{ Intention to use (INT) } & Y1.1 & 0.822 & 0.000 & Valid \\
\hline & Y1.2 & 0.884 & 0.000 & Valid \\
\hline & $\mathrm{Y} 1.3$ & 0.821 & 0.000 & Valid \\
\hline
\end{tabular}

Appendix (B)

\begin{tabular}{|l|l|l|}
\hline Variable & Alpha Chronbach's & Information \\
\hline Perceived Usefulness (X1) & 0.772 & Reliable \\
\hline Perceived Ease of Use (X2) & 0.768 & Reliable \\
\hline Trust (X3) & 0.791 & Reliable \\
\hline Awareness (X4) & 0.752 & Reliable \\
\hline Intention to Use (Y1) & 0.843 & Reliable \\
\hline
\end{tabular}

